\title{
River corrections and long-term changes in flood risk in the Aare valley, Switzerland
}

\author{
Andreas Zischg ${ }^{1, a}$ \\ ${ }^{1}$ Institute of Geography, Oeschger Centre for Climate Change Research, Mobiliar Lab for Natural Risks, University of Bern, 3012 Bern, \\ Switzerland
}

\begin{abstract}
Flood risk is changing over time. Beside climatic changes, key drivers for changing flood risks are the modification of the river courses by flood defence structures and the increase in properties exposed to floods due to economic development. In this study, both effects - the modification of the river courses and the increase of economic assets - on the long-term evolution of flood risk were isolated and confronted. To this aim, two states of the river network were compared, one representing the river courses of today and another representing the river courses of the early $19^{\text {th }}$ century before the river corrections took place. Selected observed and well documented flood events of the last decades were modelled on the historic states of the river reaches. The documented flood events were compared with the simulations in terms of inundated area and exposed buildings. Without river corrections, the flooded areas and the number of exposed residential housings would be remarkably higher than observed in recent flood events. The examples show that the effects of the main river corrections are remarkable for today's economic activities in the floodplains. Therefore, the maintenance of the former river correction works is an important part of today's risk management practice.
\end{abstract}

\section{Introduction}

Flood risk in terms of the probability of damages to persons, houses and infrastructure due to floodings is changing over time. The most important drivers for longterm changes (from decades to centuries) are climatic changes, changes in the runoff behaviour of the catchments, changes in the hydromorphologic state of the river courses and changes in the values at risk. For analysis of long-term changes in river systems, their historic states have to be reconstructed. This is done for many purposes. Historic floods are reconstructed for raising information about extreme events. The consideration of former extreme flood events can extent the time periods of discharge measurements and therefore improve flood frequency estimation (e.g. [1], [2], [3], [4], [5], [6], [7]). An overview of quantitative historical hydrology in Europe is given by [8]. Another use of reconstructed historical floods is the analysis of changes of the meteorological causes of floods (e.g. [9]). Other studies focus on the environmental changes in the river courses itself and their consequences for floods (e.g. [10], [11]). A third group is analysing the alteration of hydrologic regimes by reconstructing or "retromodelling" historic states of the river channels and comparing them with the today's river channels (e.g. [12], [13]).
But, the question about the effect of the historic river corrections to the exposure of persons and values is rarely investigated. The aim of this study is therefore to quantify the effects of the river corrections in terms of the reduction of exposure of residential buildings to floods. The main hypothesis is that the actual morphology of the river courses as a sum of all anthropogenic modifications reduces the damage potential of rare floods remarkably. Thus, the main research question is to quantify this effect in terms of changes in number of exposed buildings to recent floods between the actual state and a historic state of the river morphology.

The study was carried out in the Aare river basin upstream of Bern, Switzerland. Most of the rivers in this catchment were regulated in the early 19th century. One important regulation, however, was realised as early as in the 18th century. The first river correction was the deviation of the Kander river into Lake Thun in 1714 ([14]). This deviation changed the hydrology and the flood frequency in Bern remarkably because of the retention effects of the lake. From 1814 on, the Aare river between Lake Thun and Bern was corrected with a uniform cross section and lateral dams [15]. These works were finished 1892. Since then, the Aare river course in this reach did not change remarkably, apart from incision into the riverbed. The Gürbe river was corrected and trained around 1850 .

\footnotetext{
$\overline{{ }^{a} \text { Corresponding author: andreas.zischg@giub.unibe.ch }}$
} 


\section{Methods}

In this study, both effects - the modification of the river courses and the increase of economic assets - on the long-term evolution of flood risk were isolated and confronted. In a first step, a historic state of the river course without any remarkable anthropogenic influences was implemented into a 2D hydrodynamic model. The historic states of the rivers Aare, Hasliaare and Gürbe before the river corrections were reconstructed by means of historic topographic maps and surveys. The historic terrain models were reconstructed by georeferencing and digitalizing historic maps and cross-sections combined with the mapping of the geomorphologic evidences of former river structures in areas not modified by anthropogenic activities ([16], [17], [18]).

In a second step, selected flood events of the last decades were modelled on the historic state of the river reaches. The results of these simulations were compared with the event documentation in terms of inundated area and number of exposed residential buildings. In a third step, the temporal development of residential buildings was quantified.

\subsection{Reconstruction of historic river courses}

The natural states of the river courses before the first relevant anthropogenic modifications took place were reconstructed on the basis of historic maps. The river corrections were planned on the basis of remarkably detailed topographic surveys. These surveys include plans and maps but also many mapped cross sections from different dates. The historic maps were georeferenced on the basis of the hillshade of the highly resoluted digital elevation model. In this model, the former river beds and channel geometries are visible, especially in those areas which are covered now by alluvial forests. These evidences already visible in the terrain provide a useful base for verifying the accurateness of the historic maps and for the georeferencing. Afterwards, the recent anthropogenic modifications of the terrain were erased from the terrain model. In a next step, the digitized areas of the historic riverbeds were incised into the cleaned terrain model. The incision depth was delineated from the historic topographic surveys and the historic cross section geometries (see figure 1 for an example of a historic cross section). The reconstructed terrain model provided the basis for the creation of the computational mesh for the hydrodynamic model.

\subsection{Hydrodynamic modelling}

The historic situation of the river courses was implemented into a 2D flood simulation model. The computational mesh was generated on the basis of recent Lidar measurements with a resolution of 4 points $/ \mathrm{m}^{2}$ outside the anthropogenically modified areas. Within the modified areas, the mesh nodes were derived from the historic terrain model. For the hydrodynamic simulation, the BASEMENT simulation model of ETHZ was used ([19]).

As flood scenarios, the flood hydrographs of the July 1990, August 2005 and October 2011 flood events were extracted from the time series of the gauging stations Gürbe at Burgistein, Aare at Thun, and Hasliaare at Brienzwiler respectively. The data was provided by the Federal Office for the Environment and the Canton of Bern.

\subsection{Temporal development of residential buildings}

Beside the changes in the river course, the number of exposed buildings is also changing over time. Therefore, this driver of changing exposure was analysed in a spatiotemporal framework following the approach of [20]. For this purpose, a dataset of the residential buildings with the year of construction was used. This dataset was provided by the Federal Office for Statistics. The classes of construction periods are: before 1919, 1919-1945, 1946-1960, 1961-1970, 1971-1980, 1981-1990, 1911995, 1996-200, 2001-2005, 2006-2010, 2011-2014. For this study, it was assumed that the buildings constructed before 1919 represent more or less the state of the mid$19^{\text {th }}$ century. The study areas were delimited on the basis of the floodplains morphology and the hillslopes of the valley bottom.

\subsection{Quantification of the effects of river corrections}

The historic state of the river course before the anthropogenic interventions was used as the terrain model for the hydrodynamic simulation. In this simulation, the observed hydrograph of the selected flood event was used as input for flood modelling. This hydrograph was measured by a gauging station. It was used as an inflow at the upper boundary of the floodplain. For the Aare river between Thun and Bern, the hydrograph of the August 2005 event measured in Thun was used. The peak discharge was $543 \mathrm{~m}^{3} / \mathrm{s}$. For the Hasliaare river reach, the hydrograph of the October 2011 event with a peak discharge of $365 \mathrm{~m}^{3} / \mathrm{s}$ was used. For the Gürbe river, the hydrograph of the July 1990 event with a peak discharge of $85 \mathrm{~m}^{3} / \mathrm{s}$ was used for modelling the historic flood scenario.

The simulated flooded areas of the historic states were compared with the event documentation dataset of the Canton of Bern. In terms of exposed buildings, the comparison between the two states of the river courses was done in the following way: In a first step, the building stock of today was intersected with the documented flooded areas of the recent events (event documentation). In a second step, the actual building stock was intersected with the simulated flooded areas of the historic terrain model (hypothetic flood without flood defence structures). In a third step, the number of exposed buildings (actual building stock) located in the documented flooded areas was compared with the building stock of 1919 exposed to the hypothetic flooded 
areas of the historic terrain model. Furthermore, the building stock of 1919 was intersected with the floodings of the historic state and the floodings of the actual state of the river course. Hence, this approach allowed to quantify a) the contribution of the river corrections to the reduction of the exposure of residential buildings, b) the effect of the growth in building stock to flood exposure, and c) the combination of both.

\section{Results}

The main results of this study are the reconstructed historic river courses. These represent a natural riverbed before the first anthropogenic interventions took place and provide the basis for further analyses of exposed residential buildings and their temporal development. With this, the basis for an analysis of the effects of the river corrections is provided.

\subsection{Reconstructed historic river courses}

Figure 2 shows an excerpt of the reconstructed terrain model of the Aare river around 1815. The river consisted of a network of channels with isolated temporary islands and occupied a width of $1000 \mathrm{~m}$ with a braided character. The Hasliaare river showed a braided character in the upper part of the floodplain and a meandering character in the lower part before flowing into Lake Brienz. The Gürbe river showed in most parts a meandering character (figure 3 ). Table 1 shows the differences in mean flow length and table 2 shows the differences in the area of flowing water.

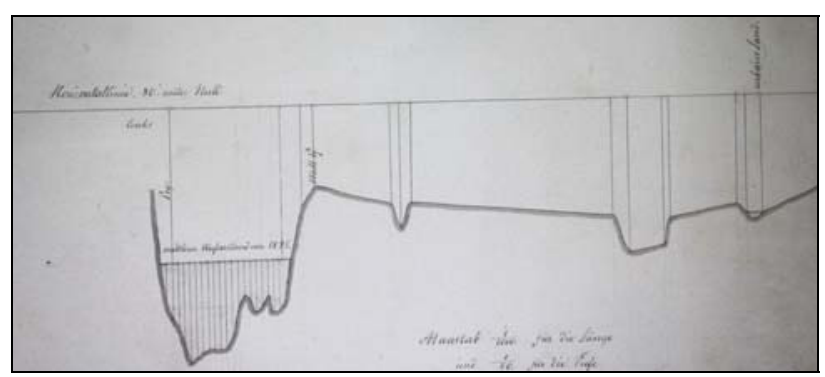

Figure 1. Example of a cross section of the Aare river 1826, near Jaberg

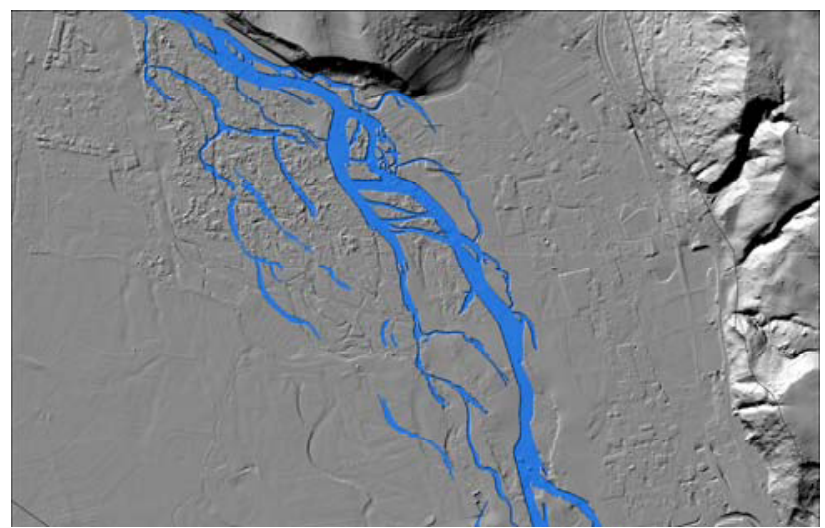

Figure 2. Extract of the reconstructed terrain model of the Aare river between Thun and Bern around 1815.

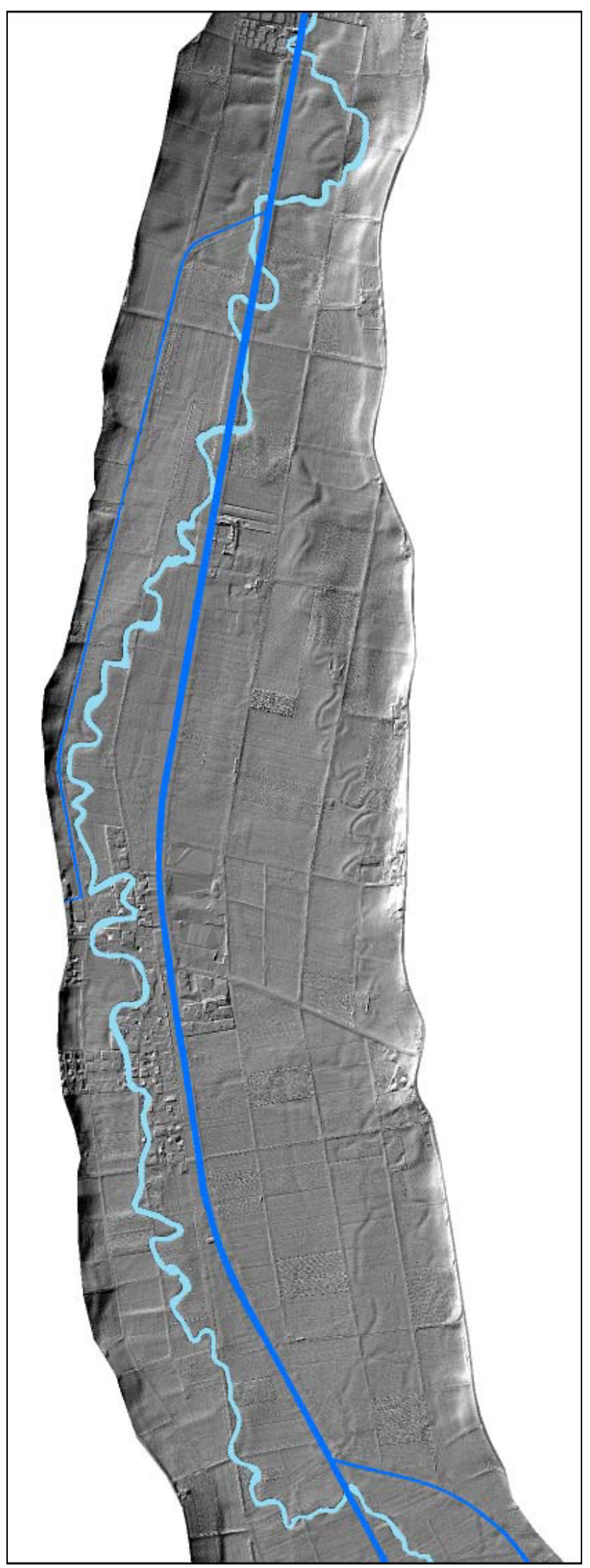

Figure 3. Reconstructed riverbed of the Gürbe river before the correction works (light blue) and the actual riverbed (dark blue). 


\begin{tabular}{|c|c|c|c|}
\hline River reach & $\begin{array}{c}\text { early-19 }^{\text {th }} \\
\text { century } \\
{[\mathbf{k m}]}\end{array}$ & $\begin{array}{c}\text { actual state } \\
{[\mathbf{k m}]}\end{array}$ & $\begin{array}{c}\text { difference } \\
{[\%]}\end{array}$ \\
\hline $\begin{array}{c}\text { Aare } \\
\text { Thun-Bern }\end{array}$ & 34.0 & 27.2 & -20 \\
\hline Hasliaare & 27.2 & 13.5 & -17 \\
\hline Gürbe & 11.8 & 17.4 & -32 \\
\hline
\end{tabular}

Table 1. Differences in flow length

\begin{tabular}{|c|c|c|c|}
\hline River reach & $\begin{array}{c}\text { early-19 } \\
\text { century } \\
{\left[\mathbf{k m}^{\mathbf{2}}\right]}\end{array}$ & $\begin{array}{c}\text { actual state } \\
{\left[\mathbf{k m}^{2}\right]}\end{array}$ & $\begin{array}{c}\text { difference } \\
{[\%]}\end{array}$ \\
\hline $\begin{array}{c}\text { Aare } \\
\text { Thun-Bern }\end{array}$ & 4.2 & 1.5 & -64 \\
\hline Hasliaare & 2.5 & 0.3 & -88 \\
\hline Gürbe & 0.4 & 0.3 & -22 \\
\hline
\end{tabular}

Table 2. Differences in flow area

The river corrections reduced the area covered by flowing water by $22-88 \%$ and the flow length by $17-32 \%$.

\subsection{Temporal development of exposed residential buildings}

In total, 7505 residential buildings are located in 2012 in the study area of the Aare river between Thun and Bern. In the study area of the Hasliaare river reach, 1514 buildings are located and in the Gürbe study area 818 residential buildings. Between 1919 and 2012, the building stock increased by $837 \%$ in the Aare river reach, by $1428 \%$ in the Hasliaare study area and by $210 \%$ in the Gürbe valley.

\begin{tabular}{|c|c|c|c|}
\hline River reach & $\begin{array}{c}\text { early-19 } \\
\text { century } \\
\text { [no.] }\end{array}$ & $\begin{array}{c}\text { actual state } \\
\text { [no] }\end{array}$ & $\begin{array}{c}\text { difference } \\
\text { [\%] }\end{array}$ \\
\hline $\begin{array}{c}\text { Aare } \\
\text { Thun-Bern }\end{array}$ & 896 & 7505 & +837 \\
\hline Hasliaare & 106 & 1514 & +1428 \\
\hline Gürbe & 389 & 818 & +210 \\
\hline
\end{tabular}

Table 3. Total number of residential buildings in the study areas (floodplains)

\subsection{Effects of the river corrections}

To compare the two states of the river reach of the Aare river between Thun and Bern, the August 2005 flood event was simulated on the basis of the historic terrain model. The inundated areas would be eight times higher in a status without any river corrections, resp. the flood defence structures reduce the flooded area about $88 \%$ (see table 4). If the building stock of 2012 is assumed to be as is in the historic flood scenario, then the number of exposed residential buildings to a flood similar to the August 2005 event but without any flood defence measures would be around forty times higher (see table 5). This means that the exposure of the actual building stock is reduced by $97.5 \%$ by the river corrections in a flood event comparable to the August 2005 flood event. However, the reduction of exposure without taking into account the economic growth would be $93 \%$ (see table 6). But, taking into account the growth of buildings, this reduction of exposure is only $69 \%$ (see table 7). Therefore, the growth of the settlements in flood prone areas reduces the effectivity of the flood protection works remarkably over time.

The comparison of the two states of the Hasliaare river reach shows a similar picture. Here, the October 2011 flood event was taken for the comparison. The flooded area would be nearly eight times higher without any flood defence measures. Therefore, the river corrections reduce the flooded areas of this scenario by $87 \%$. If the building stock is assumed as constant over the whole period (building stock of 2012), then the number of exposed buildings would be around 48 times higher in the historic scenario without the river corrections. This means that the exposure of the actual building stock is reduced by $98 \%$ in a flood event comparable to the October 2011 flood event. But, taking into account the growth of buildings, this reduction of exposure is only $87 \%$.

In the Gürbe river reach, the results differ remarkably from the other cases. Here, the historic scenario affects less buildings than the actual scenario. From the building stock of 2012, 217 residential buildings are located within the documented flooded areas of the July 1990 flood event whereas only 182 are exposed to the same flood event but on the historic terrain model. If we consider the economic growth, the increase of exposure to this flood is about $700 \%$. There are two main reasons for this. As shown in figure 3, the Gürbe river flows now in a totally different location than 1850 . The corrected river course transports the water towards the villages Mühleturnen and Toffen. In these villages, the most damages occurred in 1990. In a historic terrain model, the flood flowed in the floodplains East of the villages. In these areas, no settlements are located. The second reason is, that the 1990 flood event was an event with a very short duration of less than 7 hours. Because of this short duration, most of the peak flow is absorbed in the floodplains of the upper part of the study area. Thus, in the lower part of the floodplain, the flood is remarkably attenuated. In contrast, the actual river course transports much more water in the lower parts of the floodplain where the most buildings are located.

\begin{tabular}{|c|c|c|c|}
\hline River reach & $\begin{array}{c}\text { early-19 } \\
\text { century } \\
{\left[\mathbf{k m}^{\mathbf{2}}\right]}\end{array}$ & $\begin{array}{c}\text { actual state } \\
{\left[\mathbf{k m}^{\mathbf{2}}\right]}\end{array}$ & $\begin{array}{c}\text { difference } \\
{[\mathbf{\%}]}\end{array}$ \\
\hline $\begin{array}{c}\text { Aare } \\
\text { Thun-Bern } \\
\text { August 2005 } \\
\text { flood }\end{array}$ & 20.4 & 2.5 & -88 \\
\hline $\begin{array}{c}\text { Hasliaare } \\
\text { October } \\
\text { 2011 flood }\end{array}$ & 8 & 1 & -87 \\
\hline Gürbe & 4.6 & 0.2 & -96 \\
\hline
\end{tabular}

Table 4. Sum of flooded area. 


\begin{tabular}{|c|c|c|c|}
\hline River reach & $\begin{array}{c}\text { early-19 }^{\text {th }} \\
\text { century } \\
\text { [no.] }\end{array}$ & $\begin{array}{c}\text { actual state } \\
\text { [no] }\end{array}$ & $\begin{array}{c}\text { difference } \\
\mathbf{1 8 1 5 - 2 0 1 2} \\
\text { [\%] }\end{array}$ \\
\hline $\begin{array}{c}\text { Aare } \\
\text { Thun-Bern } \\
\text { August 2005 } \\
\text { flood }\end{array}$ & 2076 & 51 & -97 \\
\hline $\begin{array}{c}\text { Hasliaare } \\
\text { October } \\
2011 \text { flood }\end{array}$ & 242 & 5 & -98 \\
\hline Gürbe & 182 & 217 & +19 \\
\hline
\end{tabular}

Table 5. Sum of exposed buildings (building stock of 2012 for both states of the river courses)

\begin{tabular}{|c|c|c|c|}
\hline River reach & $\begin{array}{c}\text { early-19 }^{\text {th }} \\
\text { century } \\
\text { [no.] }\end{array}$ & $\begin{array}{c}\text { actual state } \\
\text { [no] }\end{array}$ & $\begin{array}{c}\text { difference } \\
\mathbf{1 8 1 5 - 2 0 1 2} \\
{[\%]}\end{array}$ \\
\hline $\begin{array}{c}\text { Aare } \\
\text { Thun-Bern } \\
\text { August 2005 } \\
\text { flood }\end{array}$ & 165 & 12 & -93 \\
\hline $\begin{array}{c}\text { Hasliaare } \\
\text { October } \\
2011 \text { flood }\end{array}$ & 39 & 2 & -94 \\
\hline Gürbe & 31 & 31 & 0 \\
\hline
\end{tabular}

Table 6. Sum of exposed buildings (building stock of 1919 for both states of the river courses)

\begin{tabular}{|c|c|c|c|}
\hline River reach & $\begin{array}{c}\text { early-19 }^{\text {th }} \\
\text { century } \\
\text { [no.] }\end{array}$ & $\begin{array}{c}\text { actual state } \\
\text { [no] }\end{array}$ & $\begin{array}{c}\text { difference } \\
\mathbf{1 8 1 5 - 2 0 1 2} \\
{[\%]}\end{array}$ \\
\hline $\begin{array}{c}\text { Aare } \\
\text { Thun-Bern } \\
\text { August 2005 } \\
\text { flood }\end{array}$ & 165 & 51 & -69 \\
\hline $\begin{array}{c}\text { Hasliaare } \\
\text { October } \\
2011 \text { flood }\end{array}$ & 39 & 5 & -87 \\
\hline Gürbe & 31 & 217 & +700 \\
\hline
\end{tabular}

Table 7 Sum of exposed buildings (building stock of 1919 with historic terrain model vs. building stock of 2012 with recent events)

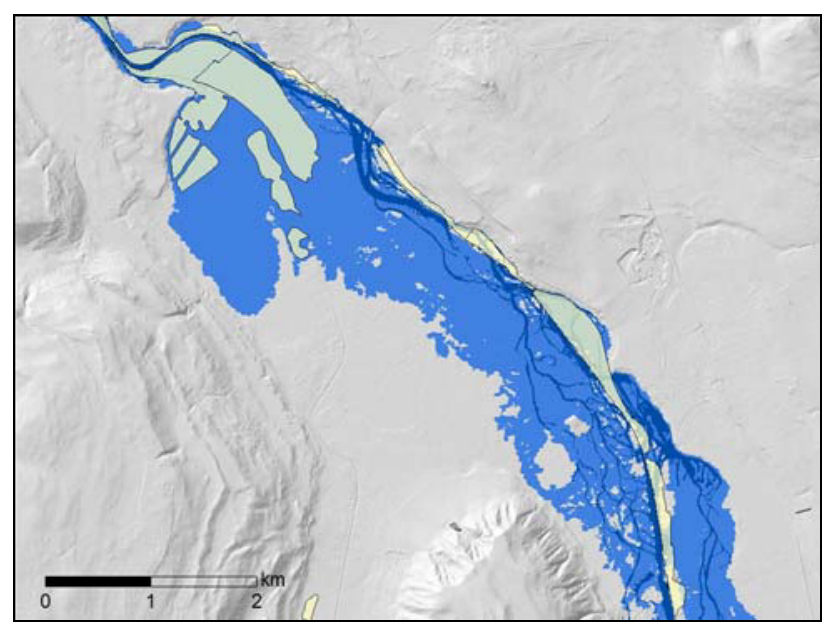

Figure 4. Comparison between the documented flooded areas of the August 2005 flood event (in yellow) in the Aare river and the hypothetic simulation of the same flood event in a historic state of the river course.

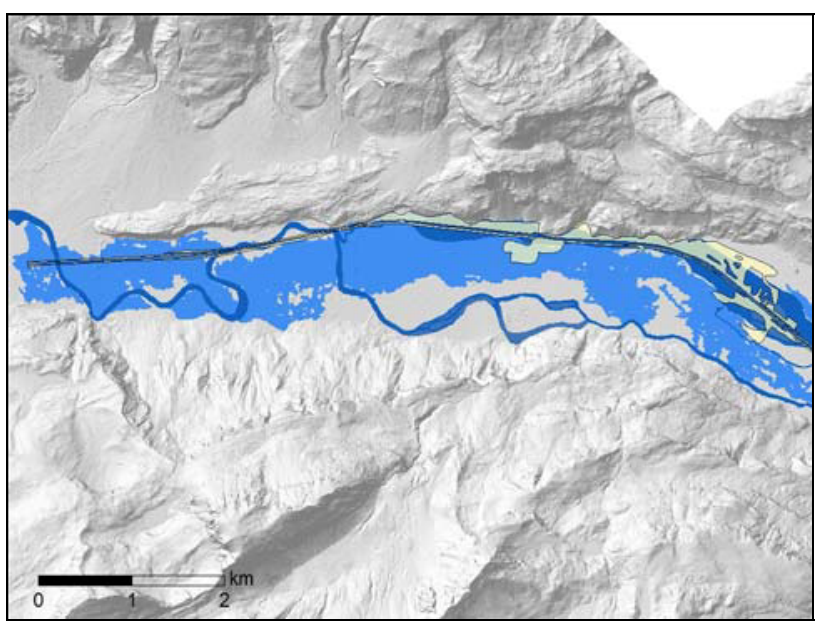

Figure 5. Comparison between the documented flooded areas of the October 2011 flood event (in yellow) in the Hasliaare river and the hypothetic simulation of the same flood event in a historic state of the river course.

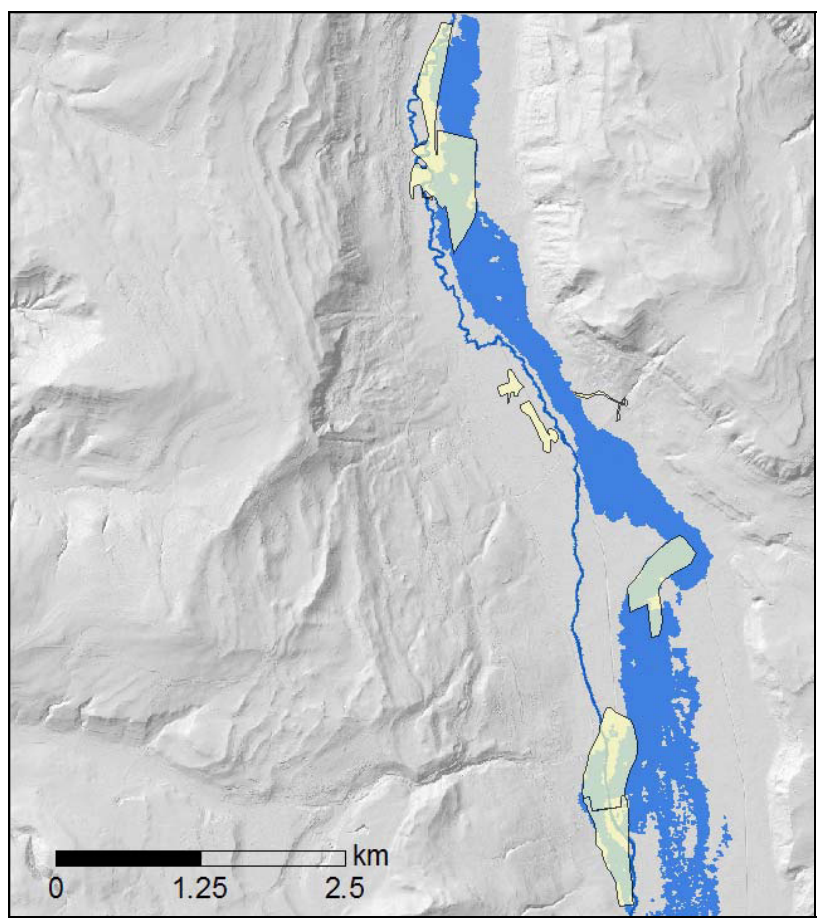

Figure 6. Comparison between the documented flooded areas of the July 1990 flood event (in yellow) in the Gürbe river and the hypothetic simulation of the same flood event in a historic state of the river course.

\section{Discussion and conclusions}

The results enable a first attempt to assess and quantify the effects of the river corrections of the $19^{\text {th }}$ century for today's flood exposure. With the first two cases, the hypothesis could be verified while the Gürbe case study leads to a falsification. It is shown, that the range in reducing the flood exposure lays between 69 and $98 \%$. But, also an increase is possible. The number of residential buildings exposed to the selected flood events would be up to forty times higher in a situation without any flood defence structures. It is also shown that the increase in the building stock reduces the effects of the 
flood defence structures remarkably. Nevertheless, the positive effects of the flood defence structures in terms of exposure reduction outweigh these compensation effects of economic growth. The latter case show that the loss of the retention effects of floodplains should be considered if assessing the effects of the river corrections in a holistic way. The special case of the July 1990 flood event in the Gürbe valley shows that the deviation of the river by the correction works is not reducing the exposure of buildings.

With this approach, arguments for the maintenance efforts could be formulated. Without a continuous maintenance of the meanwhile 150-year-old flood defence structures, the damages would be remarkably higher in case of a collapse. However, the example of the Gürbe river reach shows a differentiated view to this topic. Here, the flood defence structures increase the number of exposed buildings. The reasons are that the location of the actual river course totally differs from the historic river course and that the retention effect of the floodplain is lost. But, this example is only representative for flood events with a very short duration. In case of longer rain events, the floodplains may be filled also in their historic status and the peak discharge may be relevant also in the lower part of the floodplain. Nevertheless, this example show that the re-allocation of the actual river course to the former place could be an interesting option in flood risk management.

The limitation of the presented approach lays in the restricted selection of the flood scenarios. For each study area, only one selected flood event was chosen for the assessment of the effectivity of the existing flood defence structures. This may lead to a constrained explanatory power. Especially, discharges below the transport capacity of the actual river reaches do not result in damages today. But, without any flood defence structures, also these discharges would result in damages. Therefore, it would be very interesting if the consideration of discharges with a medium frequency lead to other conclusions than drawn here. With more scenarios, the effectivity of the existing flood defence structures could be assessed in more detail. Another limitation of the presented approach is the validation of the hydrodynamic model of the historic status. The extents of historic floods are not known in detail. So, the reliability of the simulated flood events cannot be assessed and the uncertainties remain rather unknown. However, sensitivity analyses showed that the extent of the flooded areas are remarkably robust. Thus, - since the flow depths were not used - the simulations were assessed as valid for the purpose of this study. A further critical point is that the inflows of the tributaries into the floodplain were not considered. The inflows are not known, therefore the effects of this omission is hardly to assess.

However, the described examples show that the effects of the main river corrections are remarkable for today's economic activities in the floodplains. The effect of the river corrections for risk reduction is higher than the increasing risk due to the economic development in the studied time period. Therefore, the maintenance of the former river correction works is an important part of today's risk management practice.

Acknowledgements: The author acknowledges the contributions of Sven Girod, Till Zaugg and Kevin Arnold for the collecting, compiling and georeferencing the historic data out of the historic maps and cross sections.

\section{References}

1. Kjeldsen T. R., Macdonald N., Lang M., Mediero L., Albuquerque T., Bogdanowicz E. et al. (2014). Documentary evidence of past floods in Europe and their utility in flood frequency estimation. Journal of Hydrology 517, pp. 963-973.

2. Wetter O., Pfister C., Weingartner R., Luterbacher J., Reist T., Trösch J. (2011). The largest floods in the High Rhine basin since 1268 assessed from documentary and instrumental evidence. Hydrological Sciences Journal 56(5), pp. 733-758

3. Bodoque J. M., Díez-Herrero A., Eguibar M. A., Benito G., Ruiz-Villanueva V., Ballesteros-Cánovas J. A. (2015). Challenges in paleoflood hydrology applied to risk analysis in mountainous watersheds A review. Journal of Hydrology 529, pp. 449-467.

4. Herget J., Roggenkamp T., Krell M. (2014). Estimation of peak discharges of historical floods. Hydrol. Earth Syst. Sci. 18(10), pp. 4029-4037.

5. Zbinden E. (2011). Das Magdalenen-Hochwasser von 1342 - der «hydrologische Gau» in Mitteleuropa. Wasser, Energie, Luft 103(3), pp. 193203.

6. Masoero A., Claps, P., Asselman N.E.M., Mosselman E., Di Baldassarre, G. (2013). Reconstruction and analysis of the Po River inundation of 1951. Hydrol. Process. 27(9), pp. $1341-1348$

7. Schulte L., Peña J. C., Carvalho F., Schmidt T., Julià R., Llorca J., Veit, H. (2015). A 2600-year history of floods in the Bernese Alps, Switzerland: frequencies, mechanisms and climate forcing. Hydrol. Earth Syst. Sci. 19(7), pp. 3047-3072.

8. Benito G., Brázdil R., Herget J., Machado M. J. (2015). Quantitative historical hydrology in Europe. Hydrol. Earth Syst. Sci. 19(8), pp. 3517-3539.

9. Himmelsbach I., Glaser R., Schoenbein J., Riemann D., Martin, B. (2015). Reconstruction of flood events based on documentary data and transnational flood risk analysis of the Upper Rhine and its French and German tributaries since AD 1480. Hydrol. Earth Syst. Sci. 19(10), pp. 4149-4164

10. Sear D. A., Newson M. D. (2003). Environmental change in river channels: a neglected element. Towards geomorphological typologies, standards and monitoring. Science of The Total Environment 310(1-3), pp. 17-23.

11. Spaliviero M. (2003). Historic fluvial development of the Alpine-foreland Tagliamento River, Italy, and consequences for floodplain management. Geomorphology 52(3-4), pp. 317-333.

12. Remo J. W.F., Pinter N. (2007). Retro-modeling the Middle Mississippi River. Journal of Hydrology 337(3-4), pp. 421-435. 
13. Pinter N., Heine R.A. (2005). Hydrodynamic and morphodynamic response to river engineering documented by fixed-discharge analysis, Lower Missouri River, USA. Journal of Hydrology 302(14), pp. 70-91.

14. Wirth S. B., Girardclos S., Rellstab C., Anselmetti, F. S. (2011). The sedimentary response to a pioneer geo-engineering project: Tracking the Kander River deviation in the sediments of Lake Thun (Switzerland). Sedimentology 58(7), S. 1737-1761.

15. Vischer D. (2003). Die Geschichte des Hochwasserschutzes in der Schweiz. Bundesamt für Wasser und Geologie. Bern

16. Girod, S. (2015). Rekonstruktion des historischen Flusslaufes der Aare zwischen Thun und Bern. Bsc Thesis. University of Bern, Bern. Institute of Geography.

17. Zaugg, T. (2015). Rekonstruktion des historischen Flusslaufes der Aare zwischen der Aareschlucht und dem Brienzersee. Bsc Thesis. University of Bern, Bern. Institute of Geography.

18. Arnold, K. (2015). Rekonstruktion des historischen Flusslaufes der Gürbe. Bsc Thesis. University of Bern, Bern. Institute of Geography.

19. Vetsch D., Siviglia A., Ehrbar D., Facchini M., Gerber M., Kammerer S., Peter S., Vonwiller L., Volz C., Farshi D., Mueller R., Rousselot P., Veprek R., Faeh R. (2016). BASEMENT - Basic Simulation Environment for Computation of Environmental Flow and Natural Hazard Simulations. ETH Zurich. Zurich.

20. Fuchs S.; Keiler, M.; Zischg, A. (2015): A spatiotemporal multi-hazard exposure assessment based on property data. Nat. Hazards Earth Syst. Sci. 15(9), pp. 2127-2142. 